\title{
Evaluation of Heavy Metals Leakage from Concretes Containing Municipal Wastewater Sludge
}

\author{
Elham Khalilzadeh Shirazi ${ }^{1} \&$ Reza Marandi ${ }^{2}$ \\ ${ }^{1}$ Department of Environmental Engineering, Graduate School of the Environmental and Energy, Science and \\ Research Branch, Islamic Azad University, Tehran, Iran \\ ${ }^{2}$ Department of Environmental Engineering- Islamic Azad University- North Tehran Branch, Tehran, Iran \\ Correspondence: Elham Khalilzadeh Shirazi, Department of Environmental Engineering, Graduate School of the \\ Environmental and Energy, Science and Research Branch, Islamic Azad University, Tehran, Iran. E-mail: \\ khalilzadeh.elham@yahoo.com
}

Received: December 2, 2011 Accepted: December 28, 2011 Online Published: June 25, 2012

doi:10.5539/ep.v1n2p176 URL: http://dx.doi.org/10.5539/ep.v1n2p176

\begin{abstract}
Nowadays an important environmental concern is to dispose of municipal wastewater sludge containing toxic heavy metals. These trace elements could be highly hazardous due to their insolubility, high toxicity, bioaccumulation and carcinogenic characterization. One of the latest common ways of sludge disposal is to use in construction materials such as concrete. The aim of this study is to examine leaching of heavy metals from concretes containing sewage sludge. For this purpose, concrete cubes were constructed with different percentages of wastewater sludge $(0,25,50,75,100)$ replaced with water. Slump and compressive strength of the samples were measured after curing times of 7, 28 and 90 days. Standard test method of NEN 7345 was used to evaluate the possibility of heavy metals leakage out of concrete including $\mathrm{Cr}^{+6}, \mathrm{Cu}^{+2}, \mathrm{Zn}^{+2}, \mathrm{Fe}^{+2}, \mathrm{Se}^{+2}$ and $\mathrm{Ba}^{+2}$. Results presented insignificant amount of heavy metals leaking out of concretes according to EPA standards.
\end{abstract}

Keywords: municipal sewage sludge, concrete, heavy metals, leaking

\section{Introduction}

Municipal wastewater sludge contaminated by pathogens, heavy metals and volatile organic materials is generated in wastewater treatment plants in high volumes. Therefore sludge management would be considered an important environmental and economic issue. Application of sludge in concrete could be an environmental friendly way of disposing. On the other hand, sludge replacement with water in concrete could be an appropriate way to decrease the high consumption of water in concrete industry. In general, high volume of water is consumed to make and cure concretes annually all around the world. In particular, 80 million cubic meters of concrete with an average cement grade of $250 \mathrm{~kg}$ is produced in Iran. It consumes 11000 million cubic meters of water to produce this amount of concrete per annum (Fotovat, Alavi Moghadam \& Maknoon, 2007). Considering that Iran regarded as low rain country and with regard to ever-increasing demand of water in recent years, which results in reduction of groundwater table, water reserves situation in Iran being assessed worse than other countries. In general, a lot of researches have been done all around the world in consumption of ash obtained from municipal wastewater sludge in construction materials including the following can be cited. Raw material in cement kilns (Lin, Chiang, \& Lin, 2005), tiles and bricks (Anderson, Elliot, \& Hickson, 2002; Luo \& Lin, 2003; Lin \& Luo, 2005) and also s a filler used in asphalt concrete applications (Wegman \& Young, 1998) or to manufacture aggregates and lightweight aggregates (Tay \& Show, 1992; Wainwright \& Cresswell, 2001; Wand \& Chiou, 2004; Cheeseman \& Virdi, 2005; Wang \& Tseng, 2005; Wang \& Chiou, 2005; Bhatty \& Eeid, 1989). The use of sewage sludge ash in cement-based materials as cement or sand replacement is also reported in few recent studies (Pan, Tseng, \& Lee, 2002; Cyr, Klysz, Julien, \& Clastres, 2003; Fontes, Barbosa, Toledo Filho, \& Goncalves, 2004; Luo, Lin, \& Kuo, 2004). In particular, no research has been done in Iran neither to use raw sewage sludge in concrete, nor to evaluate heavy metals leakage out of it. Only a study was performed in the United States by Cronin (2006). Based on that, a method of making concretes containing sludge can be put into practice in industrial scale. Accordingly, wastewater sludge is fed from a container to a mixing truck by way of a conveyor. The conveyor has load cells connected thereto to carefully monitor the amount of wastewater being delivered to the mixing truck. The wastewater is placed in a paddle mixer of the mixing truck wherein it is 
blended with an alkaline solution. Once the wastewater and and alkaline solution have been mixed sufficiently, a pump on the mixing truck is actuated to pump the wastewater and alkali mixture through a flexible hope pipe to a mixing drum has already contained therein a thoroughly blended mixture of cement and aggregate. Once the alkali solution and the wastewater have been added to the mixing drum containing the aggregate and cement, the mixing drum is rotated, thereby blending the materials contained therein to form a concrete mixture.

Motivations to evaluate the release of heavy metal concentrations to environment is due to its health and environmental hazards (e.g. mercury, cadmium, arsenic, lead, chromium), causing corrosion (e.g. zinc, lead), or to be harmful (e.g. arsenic may pollute catalysts). One of the major problems related to persistence of heavy metals, is their potential to bioaccumulate and biomagnificate, causing heavier exposure for some organisms which are present in the environment. Heavy metals such as $\mathrm{Cr}, \mathrm{Cu}, \mathrm{Zn}, \mathrm{Se}, \mathrm{Cd}, \mathrm{Ba}$ are categorized as polluted ones. Long-term exposure of humans to cadmium causes renal disfunction, obstructive lung disease, lung cancer and damage to human's respiratory systems. Copper is an essential substance to human life, but its high doses can cause anemia, liver and kidney damage, stomach and intestinal irritation. Chromium is used in metal alloys and pigments for paints, cement, paper, rubber, and other materials. Low-level exposure can irritate the skin and cause ulceration. Long-term exposure can cause kidney and liver damage, circulatory and nerve tissue. Hexavalent chromium is toxic to microorganisms; a property utilized in chromium-based biocides. Chromium can make fish more susceptible to infection. It can accumulate in various fish tissues and in invertebrates such as snails and worms. Hexavalent chromium is accumulated by aquatic species leads in passive diffusion. In addition, Chromium in high concentrations can be toxic for plants. Selenium causes damage to circulatory tissue and nervous system (Martin \& Griswold, 2009). In order to guarantee an appropriate use of concrete containing sewage sludge throughout its entire life cycle, the environment should not be adversely affected, especially during its service life. Thus values of heavy metals which may release from concrete to environment and pollute water and soil, should be examined

According to the results of many previous studies, leaching tests of heavy metals leached out of concrete, were conducted based on the long and short terms with the same amount of sludge and other kinds of wastes (Shi \& Kan, 2009). In other words, the relationships between leaching concentrations of heavy metals and leaching time were discussed (Hillier, Sangha, Plunket, \& Walden, 1999). In the first place, immobilization effect of cement on materials was concluded as an important factor in most of them. In the second place, strong positive relationships between the leaching concentration of heavy metals and leaching time were deducted. Furtheremore, most of the leached heavy metals were concluded to produce at early ages (Giergiczny \& Krol, 2008). On the contrary, this research has been done in terms of the comparison of leaching values of heavy metals leached out of concretes with different volumes of sludge substituted with water.

\section{Materials and Methods}

\subsection{Sewage Sludge Composition}

Table 1 gives information on components of the wastewater sludge from Qhods treatment plant in Tehran. The test was performed in the Materials Department of Science and Technology University using XRD test (PW 4015) (Azároff, Kaplow, Weiss, Kato, Wilson, \& Young 1974). (Note 1).

\subsection{Manufacturing Specimens}

To study concrete consisting of Portland cement and sewage sludge, five percentages of sludge were studied in the cement mix: Reference concrete or $0 \%, 25 \%, 50 \%, 75 \%$ and $100 \%$ sludge. Table 2 describes the materials, used in the concrete. Water/cement ratio and cement grade were fixed at 0.45 and $350 \mathrm{~kg} / \mathrm{m}^{3}$ respectively. Concrete compression in moulds was performed by vibration table (Neville, 2005).

\subsubsection{The Process of Making the Mixture for the Concrete Specimens}

In the process of making the specimens, the sludge was mixed with the cement to achieve a homogeneous mixture.

All the concretes had a fluid consistency (Abram's cone slump of between 2 and $4 \mathrm{~cm}$ ). They were made according to the ASTM C143-90a (1998).

\subsubsection{Conserving the Specimens}

The specimens were placed in a moist chamber at a temperature of $20^{\circ} \mathrm{C}$ and a minimum relative humidity of $95 \%$ until they were removed from their moulds. The time of the specimens removal from the moulds was 24 hours.

Once the specimens had been removed from the moulds, they were returned to the moist chamber under the 
same conditions as before, and their curing process was continued until they were used in the corresponding tests. Compressive strength of samples was measured according to ASTM C 109-99 standard (1999). In all curing times, 2 samples were tested for compressive strength and their average value was considered the compressive strength.

Whereas the compressive strength of concrete blocks containing sludge at different times of sampling were compared with each other, and all blocks were prepared and maintained in the same conditions. Factors such as concrete compression, mixture rate, temperature, humidity, cement type and coarse and fine aggregates grading in all tests were considered fixed.

\section{Leaching Test of NEN 7345 Leaching Test}

Various types of monolithic leaching tests have been developed in Europe in order to assess the long-term potential and velocity of leaching in matrices with long-term stabilized waste products. The most common is the Dutch test, the Netherlands Tank Leaching Test (NTLT). According to the classification of the type of specific leaching tests, the NEN-7345 test (1993) is a migration velocity test. Concrete samples $(0,25,50,75$ and $100 \%$ replacing of sludge with water) were exposed to aforesaid leaching test. Concentrations of heavy metals in leachate were examined with Atomic Adsorption (Gbs model (932 plus)), and results were compared to EPA Standards for heavy metals MCLs in drinking water.

\section{Result and Discussion}

According to the following results of sludge chemical analysis, various concentrations of heavy metals were obtained. It shows that the contents of $\mathrm{Fe}, \mathrm{Zn}, \mathrm{Se}, \mathrm{Cu}, \mathrm{Ba}$ and $\mathrm{Cr}$ are 8.13, 0.26, 0.14, 0.07, 0.95 and 2.86\% respectively.

Table1. Chemical characterization of Qhods wastewater sludge

\begin{tabular}{cc}
\hline Elements and heavy metals & The heavy metals and elements content in sewage sludge (\%) \\
\hline $\mathrm{Ca}$ & 59.37 \\
$\mathrm{Si}$ & 14.13 \\
$\mathrm{Fe}$ & 8.13 \\
$\mathrm{P}$ & 7.67 \\
$\mathrm{Al}$ & 4.59 \\
$\mathrm{Mg}$ & 1.86 \\
$\mathrm{~K}$ & 1.22 \\
$\mathrm{Ti}$ & 0.899 \\
$\mathrm{Na}$ & 0.729 \\
$\mathrm{~S}$ & 0.424 \\
$\mathrm{Zn}$ & 0.265 \\
$\mathrm{Cl}$ & 0.224 \\
$\mathrm{Se}$ & 0.148 \\
$\mathrm{Mn}$ & 0.130 \\
$\mathrm{Cu}$ & 0.0758 \\
$\mathrm{Ba}$ & 0.957 \\
$\mathrm{Zr}$ & 0.0229 \\
$\mathrm{Cr}$ & 2.86 \\
\hline
\end{tabular}

Concentrations of $\mathrm{Fe}, \mathrm{Ba}, \mathrm{Se}, \mathrm{Zn}, \mathrm{Cu}$ and $\mathrm{Cr}$ were considered to measure in concrete leaching test which the results will be shown in Table 3. According to the results of leaking test, $\mathrm{Cr}$ and $\mathrm{Cu}$ concentrations in leachates of concrete cubes with 25,50 and $75 \%$ sludge, $\mathrm{Zn}$ and $\mathrm{Ba}$ in all samples, Fe and $\mathrm{Se}$ in 25 and $50 \%$ concrete blocks are lower than determined limitations in EPA standards. 
Table 2. Mixing Mass concrete

\begin{tabular}{ccc}
\hline \multicolumn{3}{c}{ Mass concrete } \\
\hline $1 \mathrm{~m}^{3}$ of concrete & Material \\
\hline $1135.5 \mathrm{~kg}$ & Fine Aggregate \\
757 & $\mathrm{~kg}$ & Coarse Aggregate \\
157.5 & $\mathrm{~kg}$ & Water \\
350 & $\mathrm{~kg}$ & Portland CEM II \\
1.05 & $\mathrm{~kg}$ & Additive-Premia 180 \\
\hline
\end{tabular}

Table 3.Concentrations of heavy metals in the leachate obtained from the concretes according to NEN-7345

\begin{tabular}{|l|l|l|l|l|l|l|}
\hline $\begin{array}{l}\text { Sludge } \\
\text { percentage }\end{array}$ & $\mathrm{Cr}^{+6}$ & $\mathrm{Cu}^{+2}$ & $\mathrm{Zn}^{+2}$ & $\mathrm{Fe}^{+2}$ & $\mathrm{Ba}^{+2}$ & $\mathrm{Se}^{+2}$ \\
\hline $25 \%$ & 0.044 & 0.43 & 0.41 & 0.27 & 0.31 & 0.024 \\
\hline $50 \%$ & 0.068 & 0.51 & 0.47 & 0.3 & 0.37 & 0.05 \\
\hline $75 \%$ & 0.081 & 0.74 & 0.51 & 0.51 & 0.58 & 0.073 \\
\hline $100 \%$ & 0.13 & 1.01 & 0.63 & 0.6 & 0.73 & 0.096 \\
\hline
\end{tabular}

Densities of concretes containing sewage sludge were measured. The results are shown in Figure 1. Five values of sludge were studied after two different curing times for the density test. Figure 1 shows the density variation according to the sludge content. Results indicate that there are little differences fluctuated between, 2.35 to 2.42 $\mathrm{gr} / \mathrm{cm}^{3}$ in density of the samples.

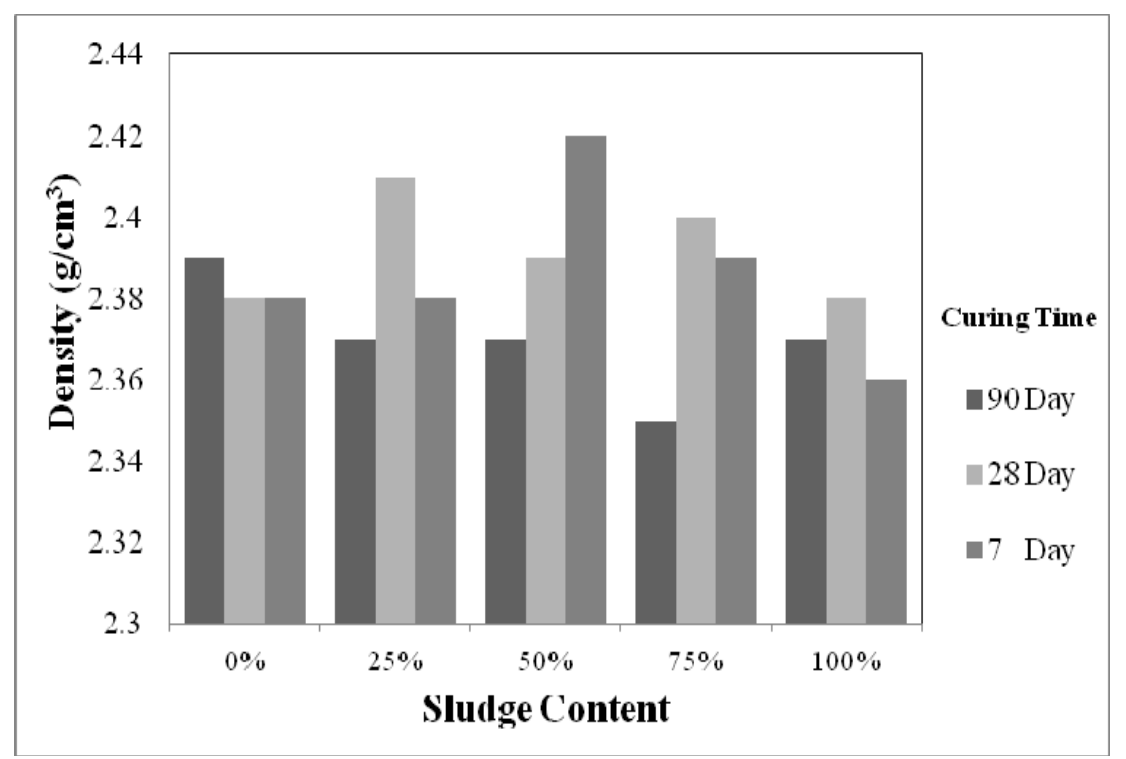

Figure1. Density varied according to the sludge content with three different curing times

The results of compressive strengths are given below (Figure 2), shown as average strength in MPa. Furthermore, after 7, 28 and 90 days, the strength characteristic of the concrete was measured. After all ages, the compressive strength tests provided us with some clear results indicating that the strength decreases slightly as the proportion of sludge increases. 


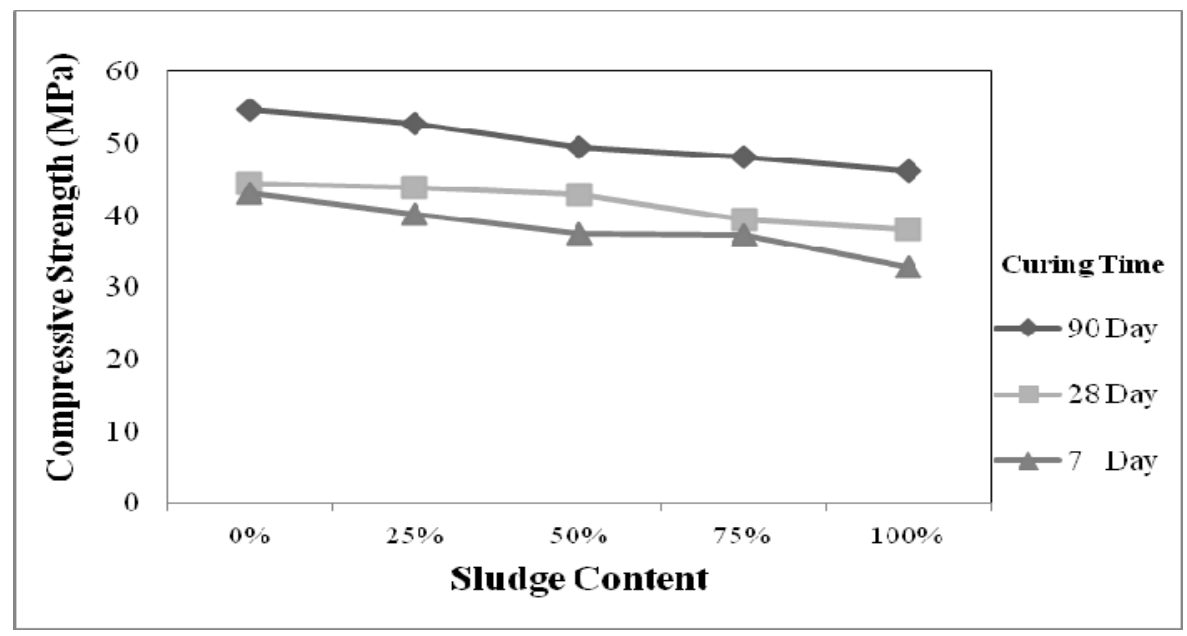

Figure 2. Compressive strength according to the sludge content with three different curing times

\section{Conclusion}

Results obtained from this study are as follows:

Evaluation of heavy metals concentrations in ppm, leaked out of concretes containing sewage sludge with different percentages, showed that concretes containing 25 and 50\% sludge replaced with water can be used according to EPA standards for limitations of heavy metals values in drinking water. The reasons for insignificant leaching of heavy metals from concretes may be considered as a very slow and gradually diluting process. Moreover, immobilization effect of cement on heavy metals should be taken into account.

The compressive strength of concretes after all curing times (7,28 and 90 days), containing different percentages of sewage sludge $(0,25,50,75$ and $100 \%)$ replaced with potable water provided us with some clear results indicating that the strength decreases slightly as the proportion of sludge increases. Otherwise, reduction of compressive strength of concrete samples, specially the ones with $50 \%$ replacement of water with sludge is too insignificant to have considerable negative effect on their application in industrial uses.

With respect to the results, no considerable losses in density and slump are concluded when sewage sludge is used in manufacturing concrete cube specimens.

This study shows that reusing wastewater sludge in manufacturing concrete, offers a possible alternative way to dispose of sludge up to $50 \%$ of its replacement with water. In this way, according to heavy metals concentrations leaked from samples in the leachate, it will be disposed of in an environmental friendly manner, in comparison with EPA standards for drinking water. On the other hand sludge replacement with water in concrete could be considered an appropriate way to reduce the high consumption of water in concrete industry.

\section{Acknowledgement}

I hereby would like to convey my sincere thanks to Mr Mehdi Ali Babaei, due to the vast instructions for this research and to respected personnel of Sang Salar Co.

\section{References}

Anderson, M. (2002). Encouraging prospects for recycling incinerated sewage sludge ash (ISSA) into clay-based building products. $J$ Chem Technol Biotechnol, 77, 352-360. http://dx.doi.org/10.1002/jctb.586

Anderson, M., Elliott, M., Hickson, C. (2002). Factory-scale proving trials using combined mixtures of three by-product wastes (including incinerated sewage sludge ash) in clay building bricks. $J$ Chem Technol Biotechnol, 77, 345-351. http://dx.doi.org/10.1002/jctb.593

Anderson, M., \& Sherratt, R. G. (2003). Variability study of incinerated sewage sludge ash in relation to future use in ceramic brick manufacture. Brit Ceram $T$, 102, 109-113. http://dx.doi.org/10.1179/096797803225001614

ASTM C 109-99. (1999). Standard test method for compressive strength of hydraulic cement mortars. American Society for Testing and Materials. 
ASTM C 143_90a. (1998). Standard test method for slump of hydraulic cement concrete. American Society for Testing and Materials.

Azároff, L. V., Kaplow, R., Weiss, N., Kato, R. J, Wilson, A. J. C., \& Young, R. A. (1974). X-ray diffraction. McGraw-Hill.

Bhatty, J. I., \& Reid, K. J. (1989). Lightweight aggregates from incinerated sludge ash. Waste Manag Res, 7, 363-376.

Cheeseman, C. R., \& Virdi, G. S. (2005). Properties and microstructure of lightweight aggregate produced from sintered sewage sludge ash. Resour Conserv Recy, 45, 18-30. http://dx.doi.org/10.1016/j.resconrec.2004.12.006

Cronin, J. G. (2006). Method of using wastewater sludge in the production of concrete. Patent Application Publication Cronin. PUB.NO: US 2006, 0112861 A1 United States.

Cyr, M., Klysz, G., Julien, S., \& Clastres, P. (2003). Les cendres d'incinération de Stations de Traitement des Eaux Polluées (STEP) sont-elles utilisables dans les matrices cimentaires? Comparaison avec les cendres volantes de charbon. Déchets Sciences et Techniques, 29, 22-29.

Fotovat, A., Alavi Moghadam, M. R., Maknoon, R., \& Sebt, M. H. (2007). Laboratory study on application of municipal sludge ash in construction materials, Proceedings of IWA special conference on Facing Sludge Diversities, Challenges, Risks and Opportunities, (IWA Antalya 2007), 28-31 March, Belek, Antalya, Turkey.

Fontes, C. M. A., Barbosa, M. C., Toledo, Filho R. D., \& Goncalves, J. P. (2004). Potentiality of sewage sludge ash as mineral additive in cement mortar and high performance concrete, International RILEM Conference on the Use of Recycled Materials in Buildings and Structures, 8-11, 797-806.

Giergiczny, Z., \& Krol, A. (2008). Immobilization of heavy metals ( $\mathrm{Pb}, \mathrm{Cu}, \mathrm{Cr}, \mathrm{Zn}, \mathrm{Cd}, \mathrm{Mn}$ ) in the mineral additions containing concrete composites. Journal of Hazardous Materials, 160, 247-255. http://dx.doi.org/10.1016/j.jhazmat.2008.03.007

Hillier, S. R., Sangha, C. M., Plunket, B. A., \& Walden, P. J. (1999). Long-Term leaching of toxic trace metals from Portland cement concrete. Cement and Concrete Research, 29, 515-521. http://dx.doi.org/10.1016/S0008-8846(98)00200-2

Lin, D. F., Luo, H. L., \& Sheen, Y. N. (2005b). Glazed tiles manufactured from incinerated sewage sludge ash and clay. JAPCA J Air Waste Ma, 55, 163-172. http://dx.doi.org/10.1080/10473289.2005.10464614

Lin, K. L., Chiang, K. Y., \& Lin, C. Y. (2005a). Hydration characteristics of waste sludge ash that is reused in eco-cement clinkers. Cement Concrete Res, 35, 1074-1081. http://dx.doi.org/10.1016/j.cemconres.2004.11.014

Lin, K. L., \& Lin, C. Y. (2005). Hydration characteristics of waste sludge ash utilized as raw cement material. Cement Concrete Res, 35, 1999-2007. http://dx.doi.org/10.1016/j.cemconres.2005.06.008

Luo, H. L., \& Lin, D. F. (2003). Evaluation of color changes in sewage sludge ash brick by using image analysis method. Pract Period Hazard Tox Radioact Waste Manag, 7, 214-223. http://dx.doi.org/10.1061/(ASCE)1090-025X(2003)7:4(214)

Luo, H. L., Lin, D. F., \& Kuo, W. T. (2004). The effects of nano-materials on the behaviors of sludge mortar specimens. Water Sci Technol, 50, 57-65.

Martin, S., \& Griswold, W. (2009). Human Health Effects of Heavy Metals. Environmental Science and Technology Briefs for Citizens, Center for Hzardous Substance Research (CHSR), 15, 785-532-6519.

NEN 7345. (1993). Determination of the release of inorganic constituents from construction materials and stabilized waste products. NNI, Delft /(Netherlands). Formerly Draft NEN 5432.

Neville, A. M. (2005). Properties of concrete. Sixth and Final Edition. England: Addison Wesley Longman Occupational Health and Safety Administration. (2004). Safety and health topics: Heavy metals. Retrieved on December 30, 2008, from http://www.osha.gov/SLTC/metalsheavy/index.html

Pan, S. C., Tseng, D. H., \& Lee, C. (2002). Use of sewage sludge ash as fine aggregate and pozzolan in Portland cement mortar. J Solid Waste Technol Manag, 28, 121-130.

Shi, H., \& Kan, L. (2009). Leaching behavior of heavy metals from municipal solid wastes incineration (MSWI) fly ash used in concrete. Journal of Hazardous Materials, 164, 750-754. 
http://dx.doi.org/10.1016/j.jhazmat.2008.08.077

Tay, J. H., \& Show, K. Y. (1992). Utilization of municipal wastewater sludge as building and construction materials. Resour Conserv Recy, 6, 191-204. http://dx.doi.org/10.1016/0921-3449(92)90030-6

Wainwright, P. J., \& Cresswell, D. J. F. (2001). Synthetic aggregates from combustion ashes using an innovative rotary kiln. Waste Manag, 21, 241-246. http://dx.doi.org/10.1016/S0956-053X(00)00096-9

Wang, K. S., \& Chiou, I. J. (2004). Foamed lightweight materials made from mixed scrap metal waste powder and sewage sludge ash. Waste Manag Res, 22, 383-389. http://dx.doi.org/10.1177/0734242X04046215

Wang, K. S., Chiou, I. J., Chen, C. H., \& Wang, D. (2005a). Lightweight properties and pore structure of foamed material made from sewage sludge ash. Constr Build Mater, 19, 627-633. http://dx.doi.org/10.1016/j.conbuildmat.2005.01.002

Wang, K. S., Tseng, C. J., \& Chiou, I. J. (2005b). M.H. Shih, The thermal conductivity mechanism of sewage sludge ash lightweight materials. Cement Concrete Res, 35, 803-809. http://dx.doi.org/10.1016/j.cemconres.2004.04.027

Wegman, D. E, \& Young, D. S. (1988) Testing and evaluating sewage sludge ash in asphalt paving mixtures. 67th Annual Transportation Research Board Meeting, Washington DC.

www.epa.gov/safewater $(2 / 2011)$ 